\section{EMBRYRIDDLE}

Aeronautical University

SCHOLARLY COMMONS
Journal of Aviation/Aerospace Education \& Research

Volume 12

Number 3 JAAER Spring 2003

Article 2

Spring 2003

\title{
An Investigation Into Factors Influencing Men and Women in Becoming Professional Pilots
}

Steven L. Anderson

David J. Pucel

Follow this and additional works at: https://commons.erau.edu/jaaer

\section{Scholarly Commons Citation}

Anderson, S. L., \& Pucel, D. J. (2003). An Investigation Into Factors Influencing Men and Women in Becoming Professional Pilots. Journal of Aviation/Aerospace Education \& Research, 12(3).

https://doi.org/10.15394/jaaer.2003.1569

This Article is brought to you for free and open access by the Journals at Scholarly Commons. It has been accepted for inclusion in Journal of Aviation/Aerospace Education \& Research by an authorized administrator of Scholarly Commons. For more information, please contact commons@erau.edu. 


\title{
AN INVESTIGATION INTO FACTORS INFLUENCING MEN AND WOMEN IN BECOMING PROFESSIONAL PILOTS
}

\author{
Steven L. Anderson and David J. Pucel
}

\begin{abstract}
Increasing the number of men and women pilots to meet future needs will require recruitment efforts based on an understanding of factors affecting the choice to be a professional pilot. This study investigated the factors that might positively or negatively influence men and women choosing to become professional pilots using force-field analysis. In addition, it investigated whether the factors differ for women and men. Random samples of 300 female and 300 male professional pilots were sent a brainstormed list of 70 factors that might influence the choice to be a pilot. The list was developed from the literature, focus groups and aviation experts. Subjects rated each factor in terms of whether it was a positive or negative influence and its strength. The overall response rate was $68 \%$.

Twenty of the factors were reported as important to both men and women. Only one factor, cost of training, was seen as a negative by both groups. Analyses of the 20 factors revealed that some of them are more important to men, while others are more important to women. Men appear to be influenced most by monetary reward, the technical and scientific nature of the occupation, the military career potential, and the glamour and mystique of flying. Additionally, men found having same gender teachers and mentors more important than women. Women found factors such as exposure to and desire to choose a non-traditional work role, opposite gender mentors and role models, desire for a challenging career, and to prove their personal abilities as more positive factors than men. Women also saw possibilities of travel and flight instructor encouragement as more important factors.
\end{abstract}

\section{Introduction}

At the time this study was conducted the air transportation industry was experiencing a shortage of qualified professional pilots. This shortage affected all levels of the industry. Flight schools, charter operators, corporations, and regional and major airlines all were having difficulty finding and retaining professional pilots.

The shortage was attributed to a combination of rapid growth in the air transportation industry and the increasing number of airline pilots (mainly Vietnam era military trained pilots) reaching mandatory retirement age. Activity in the air transportation industry was expanding at rates of five to ten percent a year. At the same time pilots in the airline transportation industry were expected to retire at rates from ten to twenty percent a year during the next decade (Hedden, 2000; Mark, 1999). Currently, the downturn in the United States economy and the tragic events of September 2001 has caused turmoil in the aviation industry and, at least temporarily, reduced the need for pilots. The problematic shortage of qualified pilots will likely reemerge as the economy eventually rebounds.

With the number of Student Pilot Certificates issued declining from 82,205 in 1991 to 58,042 in 2000 (FAA, 2002), more students will be required to fill the anticipated need for professional pilots (Hedden, 2000). There are currently industry-wide efforts underway to boost student pilot starts such as the Be-A-Pilot program (Be a pilot, 2002) and the Aircraft Owners and Pilots Association's Project Pilot (AOPA, 2002). Although there is a need for more men and women to become interested in becoming pilots, the small numbers of women pilots suggests that women may be an untapped source. Women represent fewer than $4 \%$ of all Federal Aviation Administration (FAA) certified professional pilots in the United States. In addition, over the past ten years that number only increased by about one percent (FAA, 2002).

Many factors have been barriers to women becoming professional pilots. One major factor has been the military as the primary source of professional pilots. Until recently women were not trained as military pilots. Another 
has been the historical negative sentiment toward women becoming professional pilots (Thornberg, 2000; Turney, 2000; Turney, 1995).

Problem

Increasing the number of men and women pilots to meet future needs will require recruitment efforts based on an understanding of factors affecting the choice to be a professional pilot. It will be important to not only understand factors that might positively influence choice, but also factors that might negatively influence it. Such information can be helpful to educators, counselors, and industry leaders in emphasizing the positive factors and trying to take action to remove the negative factors.

This report presents a study that investigated the factors that might positively or negatively influence men and women choosing to become professional pilots. In addition, it investigated whether the factors differ for women and men.

\section{Career choice literature revien}

There is a large body of research on general career choice, career development, and non-traditional career choice. Although this research does not specifically include aviation career choice, it does offer insight into factors that might influence professional pilot career choice. The research points at many recurring themes that influence career choice among men and women including the following: their tendencies to pick traditional work roles, family influences, societal influences, peer pressure (Freeman, 1997; Bee, 1996; Lankard, 1995; Gunn, 1994), the importance of role models and mentors (Kerka, 1998; Jewett, 1996; Kelly, 1993), the influence of teachers and guidance counselors, the impact of early experiences (Furlong \& Biggart, 1999; Stitt-Gohdes, 1997; Lent, Hackett, \& Brown, 1996), and the differing views of men and women about career aspects (Gati, Osipow, \& Givon, 1995).

A number of recommendations for encouraging more women to pursue traditional male dominated careers have emerged. Parents and teachers should provide support and encouragement for girls who show early interest and aptitude towards science, mathematics, and technology in order to help overcome societal pressures regarding pursuit of non-traditional roles (Farenga \& Joyce, 1997; Jewett, 1996). Educators need to overcome unintentional biases towards traditional roles and offer more support and encouragement to female students in the areas of science, mathematics, and technology (Jewett, 1996; Gunn, 1994).
Young women should be provided good female mentors who can aid in overcoming the problems they will encounter in pursuing non-traditional interests. Female role models should be presented to students through the use of classroom speakers, use of females in classroom examples, and by having textbooks with examples of female contributions and work (Kerka, 1998; Greene \& StittsGohdes, 1997; Jewett, 1996; Kelly, 1993).

Method

The study was conducted using a methodology called force-field analysis (Harrison, Shirom, 1999; Lewin, 1951). It is based on the premise that there are both positive and negative factors that influence individual decisionmaking. The extent to which each factor influences a person's decision is based on how important it is to the individual. This importance is called factor strength. If the sum of the strengths of the positive factors influencing a choice outweigh the sum of the strengths of the negative factors, a person will make a positive choice. The reverse is also true.

The first phase of implementing this methodology is to identify the range of factors that might have positive or negative influences on a decision. The second phase, is to ask those knowledgeable about the particular choice to be made to rate each factor according to the strength of its influence as a positive or negative factor (Harrison, Shirom, 1999; Rothwell, Sullivan, McLean, 1995).

This study implemented the force-field methodology in three stages. First, factors that might affect a person's decision to become a professional pilot were identified. This was accomplished by developing an initial list based on a review of the literature, and two brainstorming sessions with seven female and 13 male volunteer university bachelor's degree aviation majors. The list was then sent to a selected group of 15 female and 15 male aviation experts identified by the staff of St. Cloud State University's aviation program. They were asked to add additional factors that might be missing. During this first stage the goal was to identify as large a list of brainstormed factors as possible. All factors suggested were added to the list. Editing was done only to remove duplicate items. Seventy factors were identified.

The second stage was to send the list of factors in the form of a rating scale survey instrument to a sample of professional pilots to determine which factors influenced their choices. It was not possible to identify people who might have considered becoming a pilot and did not. 
Therefore, an assumption was made that by studying women and men who were already professional pilots, inferences could be made about individuals who did not choose to become pilots.

The population of professional pilots within the United States was identified through a commercially sold CD containing the 1998 FAA database of pilots' names and addresses (Avantext, Inc.) Random samples of 300 female and 300 male pilots were drawn. The first 250 within each sample were considered to be the primary sample. The $\mathbf{5 0}$ additional people in each sample were designated as random alternates to replace people whose surveys were never delivered due to an inaccurate address.

The survey instrument had two parts. The first gathered demographic data from the subjects on three variables: gender, number of years as a professional pilot, and type of pilot. The three types of professional pilots were airline, corporate/charter, and "other" pilots. The second part contained a rating scale designed to allow subjects to rate the extent to which they felt each of the $\mathbf{7 0}$ factors identified during brainstorming influenced their decision to become a pilot. Subjects rated each factor using the following scale:

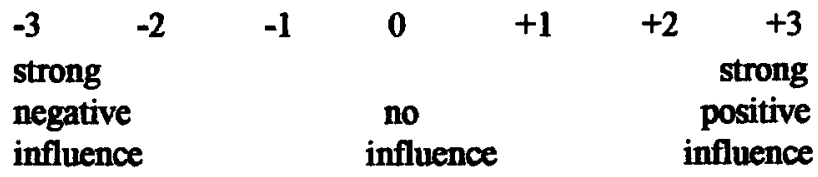

Positive ratings indicated a factor had a positive influence and negative ratings indicated it had a negative influence. A rating of zero indicated it had no influence. It was decided that a zero rating would be defined as a rating between -.5 and +.5 because less than .5 would be rounded to zero. Therefore, in order for a rating to be considered it would have to be less than -.5 or to be positive it would have to larger than +.5 .

\section{Data gathering}

Once the instrument was developed it was sent with a cover letter explaining the study to all 300 male and 300 female pilots. In addition two follow-up mailings were sent to those who did not respond. During the three mailings 52 male and 56 female survey instruments were returned incomplete because of bad addresses. Since two more inaccurate addresses were found for males and 6 more were found for females the effective sample was 248 males and 244 females. This resulted in an overall response rate was $68 \%(333 / 492)$. The response rate from the males was $66 \%(163 / 248)$ and the response rate from the females was $70 \%(170 / 244)$.

Results

Demographic data: The demographic variables of type of pilot and years as a professional pilot were analyzed to determine if there were significant differences between males and females. The data are presented in Tables 1 and 2. Results of Chi-Square analyses revealed that there was no significant difference in the distributions of types of pilots between males and females $\left(\mathrm{X}^{2}=1.853, \mathrm{p}=.396\right)$. The largest number of pilots were airline and the smallest number were corporate. However, there was a significant difference in the length of time the males and females had been pilots $\left(X^{2}=36.732, p<.000\right)$. The males tended to have been pilots for a longer period of time than females.

Table 1

Types of Professional Pilots for Males and Females

\begin{tabular}{|c|c|c|c|c|}
\cline { 2 - 5 } \multicolumn{1}{c|}{} & \multicolumn{3}{c|}{ Type of Pilot } & \\
\cline { 2 - 5 } \multicolumn{1}{c|}{} & Airline & Corporate & Other & Total \\
\hline Male & 76 & 35 & 66 & 163 \\
\hline Female & 69 & 35 & 52 & 170 \\
\hline Total & 145 & 70 & 118 & 333 \\
\hline
\end{tabular}


Table 2

Amount of Time as a Professional Pilot for Males and Females

\begin{tabular}{|c|c|c|c|c|}
\cline { 2 - 5 } \multicolumn{1}{c|}{} & \multicolumn{3}{c|}{ Years as a Professional Pilot } & \\
\cline { 2 - 5 } & $0-10$ Years & $11-20$ Years & $21+$ Years & Total \\
\hline Male & 25 & 57 & 81 & 163 \\
\hline Female & 64 & 71 & 35 & 170 \\
\hline Total & 89 & 128 & 116 & 333 \\
\hline
\end{tabular}

Positive and negative influences: The factors that positively and negatively influenced choices to become professional pilots were analyzed by first calculating the mean ratings to each factor for males and females. Positive means meant the factors had a positive influence and negative means meant they had a negative influence. The factors were then placed in rank-order according to the means separately for the females and males. The rankorders assigned by males and by females were compared using a rank-order correlation. The rank order correlation indicated that the ordering of the factors by both men and women was very similar $(r=.77, p<.05)$. Because of this overall similarity the ratings of the men and women were combined and overall mean ratings were placed in rank order to represent the ratings of the total group as presented in Table 3.

Sixty of the 70 factors were found to have a positive influence on career choice and 10 were found to have a negative influence. After applying the decision rule that mean ratings between -.5 and +.5 would be treated as zero ratings, 33 factors were identified as positive and only one was negative. Those that fell between -.5 and +.5 are indicated in Table 3 in italics. Cost of required training/education was the only negative factor remaining.

A review of the positive factors suggests that they can be categorized into the following themes.

- Enjoyment of aviation

- Support of peers and flight instructors

- Perception of career and education requirements

- Desire for challenge and responsibility

- Early exposure to aviation, science, and technology

- Perception of potential income and lifestyle 
Table 3

Rank Order of Career Choice Imfluence Factors for All Respondents

\begin{tabular}{|c|l|c|}
\hline Rank & \multicolumn{1}{|c|}{ Influence Factors } & Mean \\
\hline 1 & Love of Flying & 2.5700 \\
\hline 2 & Interest in Aviation & 2.5300 \\
\hline 3 & Desire for Challenging Career & 2.1400 \\
\hline 4 & Perceived as a Fun Profession & 1.8700 \\
\hline 5 & Perceived as an Adventurous Profession & 1.7200 \\
\hline 6 & Desire to Prove Personal Abilities & 1.7000 \\
\hline 7 & Desire for Career with a High Level of Responsibility & 1.6800 \\
\hline 8 & Desire to Travel & 1.5200 \\
\hline 9 & Perception of Achievable Lifestyle & 1.4300 \\
\hline 10 & Perceived Prestige of Being a Professional Pilot & 1.4000 \\
\hline 11 & Perceived Travel Benefits & 1.3700 \\
\hline 12 & Perceived Career Advancement Possibilities & 1.3300 \\
\hline 13 & Perceived Technical Nature of Profession & 1.3200 \\
\hline 14 & Support and Encouragement of Flight Instructor(s) & 1.2600 \\
\hline 15 & Earty Exposure to Aviation & 1.2500 \\
\hline 16 & Perceived Innate Ability & 1.1900 \\
\hline 17 & Desire to Pursue Non-Traditional Work Role & 1.0600 \\
\hline 18 & Perceived Potential Income & 1.0400 \\
\hline 19 & Desire for a Technical Profession & 1.0300 \\
\hline 20 & Exposure to Science/Technology at Young Age & 1.0000 \\
\hline 21 & Perceived as a Glamorous Profession & 0.9900 \\
\hline 22 & Perceived Knowledge Requirement & 0.9700 \\
\hline 23 & Parental Support & 0.9000 \\
\hline 24 & Desire to Serve Others & 0.7900 \\
\hline 25 & Training Methods Used & 0.7700 \\
\hline 26 & Knowledge of Professional Pilot Career Options & 0.7500 \\
\hline 27 & Peer Support & 0.7000 \\
\hline 28 & Availability of Math/Science Courses in High School & 0.6400 \\
\hline 29.5 & Perceived Training Requirements & 0.5600 \\
\hline 29.5 & Exposure to AviationMystique (i.e. Hollywood Pottraval & 0.5600 \\
\hline 31 & Same Gender Role Model(s) & 0.5400 \\
\hline 32 & Military Career Potential & 0.5300 \\
\hline 33 & Desire for Authority & 0.5200 \\
\hline 34.5 & Same Gender Mentor & 0.4600 \\
\hline 34.5 & Perceived Societal Support & 0.4600 \\
\hline
\end{tabular}


Table 3 (continued)

Rank Order of Career Choice Influence Factors for All Respondents

\begin{tabular}{|c|l|c|}
\hline Rank & \multicolumn{1}{|c|}{ Influence Factors } & Mean \\
\hline 36 & Exposure to Non-Traditional Gender Roles & 0.4400 \\
\hline 37 & Family Member (other than parent) was/is a Pilot & 0.4200 \\
\hline 38 & Opposite Gender Mentor & 0.4000 \\
\hline 39 & Encouragement to take Math/Science/Technical & 0.3800 \\
\hline 40 & & \\
\hline 41 & Opposite Gender Role Model(s) & 0.3500 \\
\hline 42 & Parent was/is a Pilot & 0.3400 \\
\hline 43.5 & Family Influence to Become a Pilot & 0.3200 \\
\hline 43.5 & Early Retirement Options & 0.2900 \\
\hline 45 & Parental Expectations for Career & 0.2900 \\
\hline 46 & Proximity to an Aviation School & 0.2400 \\
\hline 47 & Perception of Same Gender Pilots by Peers & 0.2300 \\
\hline 48 & Expectations of Math/Science Teacher(s) & 0.1800 \\
\hline 49 & Perceived Family Life Impact & 0.1700 \\
\hline 50 & Knowledge of Equal Employment Opportunity Rules & 0.1400 \\
\hline 51 & Perceived as a Dangerous Profession & 0.1300 \\
\hline 52.5 & Opposite Gender Flight Instructors & 0.1200 \\
\hline 52.5 & Amount of Time Required to Become a Professional & 0.1100 \\
\hline 54 & Availability of Same Gender Flight Instructors & 0.1100 \\
\hline 55 & Perceived Medical Requirements & 0.0721 \\
\hline 56 & Amount of Training/Education Required & 0.0661 \\
\hline 57 & Parent was is a Professional Pilot & 0.0631 \\
\hline 58 & Historical Hiring Patterns & 0.0541 \\
\hline 59 & Same Gender Math/Science Teacher(s) & 0.0480 \\
\hline 60 & Desire to Pursue Traditional Work Role & 0.0360 \\
\hline 61 & Gender Role Stereotyping & 0.0150 \\
\hline 62 & Participation in Youth Aviation Program(s) & -0.0270 \\
\hline 63 & Perceived Male Domination of Profession & -0.0390 \\
\hline 64 & Peer Pressure to Choose Traditional Work Role & -0.0511 \\
\hline 65 & Perception of Failure Rate & -0.0570 \\
\hline 66 & Societal Pressure to Choose Traditional Work Role & -0.0721 \\
\hline 67.5 & Family Pressure to Choose Traditional Work Role & -0.0781 \\
\hline 67.5 & Support of High School Guidance Counselor(s) & -0.1100 \\
\hline 69 & Availability of High School Aviation Course(s) & -0.1100 \\
\hline 70 & Cost of Required Training/Education & -0.1700 \\
\hline
\end{tabular}




\section{Table 4}

Factor Differences Between Male and Female Respondents

\begin{tabular}{|c|c|c|c|c|}
\hline Influence Factor & $\begin{array}{l}\text { Male } \\
\text { Mean }\end{array}$ & $\begin{array}{l}\text { Female } \\
\text { Mean }\end{array}$ & $\begin{array}{l}\text { Diff. } \\
\text { in } \\
\text { Means }\end{array}$ & $\begin{array}{l}\text { T-Value } \\
\text { (P-value) }\end{array}$ \\
\hline Perceived Potential Income & 1.1800 & 0.9100 & -.27 & $\begin{array}{l}2.132 \\
(.034)\end{array}$ \\
\hline $\begin{array}{l}\text { Required High School Math and Science } \\
\text { Courses }\end{array}$ & 0.5000 & 0.1800 & -.32 & $\begin{array}{l}2.984 \\
(.003)\end{array}$ \\
\hline Perceived as a Glamorous Profession & 1.2100 & 0.7800 & -.43 & $\begin{array}{l}3.641 \\
(.000)\end{array}$ \\
\hline Desire to Pursue Non-Traditional Work Role & 0.7200 & 1.3900 & .67 & $\begin{array}{l}-5.040 \\
(.000)\end{array}$ \\
\hline Perceived Technical Nature of Profession & 1.5000 & 1.1500 & -.35 & $\begin{array}{l}2.925 \\
(.004)\end{array}$ \\
\hline Exposure to Science/ Technology at Young Age & 1.2000 & 0.8100 & -.39 & $\begin{array}{l}3.023 \\
(.003)\end{array}$ \\
\hline Opposite Gender Role Model(s) & 0.0000 & 0.6900 & .69 & $\begin{array}{l}-6.695 \\
(.000)\end{array}$ \\
\hline Same Gender Mentor & 0.6200 & 0.3100 & -.31 & $\begin{array}{l}2.758 \\
(.006)\end{array}$ \\
\hline Opposite Gender Mentor & -0.0123 & 0.8000 & .81 & $\begin{array}{l}-7.955 \\
(.000) \\
\end{array}$ \\
\hline Perceived Travel Benefits & 1.2300 & 1.4900 & .26 & $\begin{array}{l}-2.145 \\
(.033) \\
\end{array}$ \\
\hline Desire for Challenging Career & 1.9400 & 2.3400 & .40 & $\begin{array}{l}-3.463 \\
(.001) \\
\end{array}$ \\
\hline Exposure to Non-Traditional Gender Roles at & 0.0859 & 0.7800 & .69 & -6.546 \\
\hline Early Exposure to Aviation & 1.5500 & 0.9600 & -.59 & $\begin{array}{l}3.906 \\
(.000)\end{array}$ \\
\hline Desire for a Technical Profession & 1.1700 & 0.8900 & -.28 & $\begin{array}{l}2.304 \\
(.022)\end{array}$ \\
\hline Cost of Required Training/Education & -0.4900 & -0.9900 & -.50 & $\begin{array}{l}3.660 \\
(.000)\end{array}$ \\
\hline Peer Support & 0.5700 & 0.8200 & .25 & $\begin{array}{l}-2.302 \\
(.022)\end{array}$ \\
\hline Exposure to Aviation Mystique & 0.7200 & 0.4000 & -.32 & 3.016 \\
\hline $\begin{array}{l}\text { Support and Encouragement of } \\
\text { Flight Instructor(s) }\end{array}$ & 0.9400 & 1.5600 & .62 & $\begin{array}{l}-5.026 \\
(.000)\end{array}$ \\
\hline Military Career Potential & 1.1000 & -0.0235 & -1.12 & $\begin{array}{l}7.727 \\
(.000)\end{array}$ \\
\hline Desire to Prove Personal Abilities & 1.5200 & 1.8700 & 35 & $\begin{array}{l}-2.927 \\
(.004)\end{array}$ \\
\hline
\end{tabular}

Note: Difference in means is the male mean subtracted from the female mean. 
Differences between male and females: Although the relative ordering of the factors by males and females were similar as indicated by the rank order correlation, differences the actual magnitude of the influence of the factors for females and males were examined for each of the factors separately. It is possible that although males and females would view the various factors similarly in terms of there rank order of influence, the actual amount of influence of the factors for males and females could be different. T-tests analyses were conducted on those factors for which either the males or females had average ratings of less than -.5 or more than +.5 . Those analyzes indicated there were significant differences between the male and female ratings at the .05 level on 20 factors. They are presented in Table 4. The differences were calculated by subtracting the male mean from the female mean to show the direction of the difference in reference to the female responses.

\section{Discussion and implications}

Although the 20 factors reported in Table 4 are important to both men and women, the analyses reported in
Table 4 indicate that some of them are more important to men and some are more important to women. Table 5 presents a summary of the factors that have a more positive influence on men and women becoming pilots and those that seem to affect both groups equally.

Men appear to be influenced most by monetary reward, the technical and scientific nature of the occupation, the military career potential, and the glamour and mystique of flying. Also, men found having same gender teachers and mentors more important than women. Women found factors such as exposure to and desire to choose a non-traditional work role, opposite gender mentors and role models, desire for a challenging career and to prove their personal abilities as more positive factors than men. They also saw possibilities of travel and flight instructor encouragement as more important factors. Although both groups saw cost of training as a negative influence, men were less influenced by the cost of training than women.

Table 5

Comparison of Influence Factors with Statistically Significant Differences at the .05 Level

\begin{tabular}{|l|l|}
\hline \multicolumn{1}{|c|}{$\begin{array}{c}\text { More Positive Influence } \\
\text { for Men }\end{array}$} & \multicolumn{1}{c|}{$\begin{array}{c}\text { More Positive Influence } \\
\text { for Women }\end{array}$} \\
\hline - Perceived Potential Income & - Desire to Pursue Non-Traditional \\
- Required High School Math and & Traditional Work Role \\
Science Courses & - Opposite Gender Role Model(s) \\
- Perceived as a Glamorous & - Opposite Gender Mentor \\
Profession & - Perceived Travel Benefits \\
- Perceived Technical Nature & - Desire for Challenging Career \\
of Profession & - Exposure to Non-Traditional \\
- Exposure to Science/ & Gender Roles at Young Age \\
Technology at Young Age & - Peer Support \\
- Same Gender Mentor & - Support and Encouragement of \\
- Early Exposure to Aviation & Flight Instructor(s) \\
- Desire for a Technical & - Desire to Prove Personal Abilities \\
Profession & \\
- Exposure to Aviation Mystique & \\
- Military Career Potential & \\
\hline
\end{tabular}


The study also indicated that although men and women seem to be affected by the same factors, some are more important to men and some are more important to women. The top 10 influence factors for the combined group of men and women in rank order from most important were:

1. Love of flying

2. Interest in aviation

3. Desire for challenging career

4. Perceived as a fun profession

5. Perceived as an adventurous profession

6. Desire to prove personal abilities

7. Desire for career with a high level of responsibility

8. Desire to travel

9. Perception of achievable lifestyle

10. Perceived prestige of being a professional pilot

These factors seem to suggest that the most important influences on a person becoming a pilot are perceptions that piloting is a challenging career that will allow a person to prove her/his abilities and that becoming a pilot is achievable. In addition pilots are perceived to have prestige and an adventuresome life with opportunities for travel. The only negative factor related to the cost of becoming a pilot.

Another important finding of this study was that men and women truly do see different factors as having different amounts of influence on their decisions to become pilots. Although people have suggested this in the literature studies have not been available to provide firm information on what those differences are. The discussion around Table 5 above presents those differences.

The information generated from this study can have a major impact on the ways in which aviation personnel address the shortage of professional pilots. In the past, aviation educators and industry leaders have mainly tried to recruit both men and women at the same time. A new strategy of recruiting men and women separately, especially women, is now starting to emerge in the industry. A better understanding of the impact on career choice of the influence factors identified in this study could improve the effectiveness of both of these recruitment strategies.

By examining the career choice influence factors identified by this study as being common to both men and women, aviation educators and industry leaders should be able to focus their resources on recruitment strategies that will have more appeal to both men and women. These recruitment strategies should be developed around the themes represented by the career choice factors that had positive influences on both men and women. Even though recruitment strategies developed around themes that appeal to both men and women might be successful in increasing the number of pilots in both groups, the greatest increases in the numbers of both female and male pilots would more likely be obtained by developing recruitment strategies that appeal separately to men and to women. To do this, influence factors identified in this study where men and women differed significantly need to be considered in recruitment.

To maximize the increase in the number of female pilots factors such as role models and mentors, peer support, and the chance to prove them selves need to be emphasized in recruiting. Strategies aimed at recruiting more male pilots should emphasize the potential income and lifestyle factors along with early exposure to aviation and science. This means that mentor programs linking high school students interested in aviation with university aviation students, like the one developed by Katsikas (1998), might be more effective in encouraging more women to pursue flying careers while advertising campaigns promoting the glamour and riches of a pilot career might be more effective in increasing the number of male pilots.

Some of the themes that were identified to be positive and negative influences on career choice in this study are familiar to aviation educators, but many are not. Past recruitment strategies have often revolved around the fun and challenge of flying, the potential income and lifestyle of being a pilot, and the cost of learning to fly. However, past recruitment efforts have not displayed an understanding of many of the other themes identified in this study such as, the importance of role models and mentors, the impact of perceived training requirements, peer support, and the desire for responsibility. To develop more effective recruitment strategies aviation educators need to become better informed about these less understood influence factors.

Literature on general and non-traditional career choice identified many of the same important influence factors as this study. For example, the importance of role models was identified as important in the literature and in this study. Aviation educators and aviation industry members should take note of the existing studies on career choice, along with the information found in this study, to 
help develop strategies for increasing the number of professional pilots. Intervention strategies suggested by researchers such as Jewett (1996) for providing role models and earty exposure to mathematics, science, and technology could be helpful guides for increasing the number of men and women choosing careers as professional pilots.

Many items were also identified as having no or very little influence on professional pilot career choice. Although valuable resources should not be expended on most of these factors, some of them might be worth further thought. For example, many studies on career choice found that high school guidance counselors and teachers are important in influencing career choice, but they were found not to have a significant influence on professional pilot career choice. This might indicate the need for more direct involvement with high school students. Activities like career fairs and aviation summer camps could be more effective in recruiting high school students interested in flying careers than sending information for guidance counselors to distribute. However, care should be taken in deciding on how much effort is expended in these low influence areas.

This study has also resulted in some suggestions for possible future research. This study identified only one factor that negatively influenced professional pilot career choice. This may have been due to the individuals in this study already being professional pilots. These people may have personally eliminated concerns about negative factors that they considered when making their decisions, therefore, they were not viewed as major issues when they participated in the study. An additional study focused specifically on the identification of negative influence factors might be helpful. Possibly a study of university aviation students who would have more recently made the. choice to pursue an aviation career might reveal more negative factors which they considered. A study focusing on how individuals in aviation first became aware of the career field could also help identify key career information sources.

To help alleviate the growing shortage of professional pilots, aviation professionals across the industry must better understand the factors that influence career choice in order to increase the number of individuals choosing flying careers. This study identified factors that influence men and women in making the choice to become professional pilots and found that many of these factors are common to both men and women. In addition, it was found that the order of influence for the career choice factors was similar between men and women while at the time men and women differed significantly on the level of many of the factors influence. Careful study and application of the information reported in this study can have a positive impact of professional pilot recruitment and help alleviate future pilot shortages. $t$

Steven L. Anderson, PhD, is an Assistant Professor in the Aviation Program at St. Cloud State University, a longtime flight instructor, a FAA Designated Pilot Examiner, and a FAA Aviation Safety Counselor. Research interests include human resource development in aviation, flight training, and aviation safety.

David J. Pucel, PhD, is a Professor of Human Resource Development and Business and Industry Education at the University of Minnesota. He is a specialist in the development and evaluation of training and development and technical education systems, has done extensive work with business and industry on selecting, training and evaluating personnel to enhance personal and job-related performance, and has authored numerous publications. 


\section{REFERENCES}

Aircraft Owners and Pilots Association (AOPA) (2002). AOPA project pilot. Available:

Ww.aopaflighttraining.org/project pilot/index.cfm

Be a pilot (2002). Available: www.beapilot.com

Bee, H. L. (1996). The journey of adulthood ( $3^{\text {rd }} \mathrm{ed}$.). New Jersey: Prentice Hill.

Farenga, S. J., \& Joyce, B. A. (1997). Beyond the classroom: Gender differences in science experiences. Education, 117(3), 563568.

Federal Aviation Administratiop (2002). U.S. civil airmen statistics 2000 available: www.api.faa.gov/civilair

Freeman, S. J. (1997). Parental influence and women's careers. In D. Dunn (Eds.), Workplace/women's place: An anthology (pp. 32-42). Los Angeles, CA: Roxbury Publishing Company.

Furlong, A., \& Biggart, A. (1999). Framing 'choices': a longitudinal study of occupational aspirations among 13- to 16-yearolds. Journal of Education and Work, 12(1), 21-35.

Gati, I., Osipow, S. H., \& Givon, M. (1995). Gender differences in career decision making: the content and structure of preferences. Journal of Counseling Psychology, 42(2), 204-216.

Greene, C. K., \& Stitts-Gohdes, W. L. (1997). Factors that influence women's choices to work in the trades. Journal of Career Development, 23(4), 265-278.

Gunn, C. (1994). Development of gender roles: Technology as an equity strategy (Report No. W2-201A). Washington, DC: U.S. Department of Education. (ERIC Document Reproduction Service No. ED 396 687).

Harrison, M. I., Shirom, A. (1999). Organizational diagnosis and assessment: Bridging theory and practice. Thousand Oaks, CA: Sage Publications, Inc.

Hedden, C. (2000, October 9). Careers 2000: Expanding the career envelope. Aviation Week \& Space Technology, 3-38. Jewett, T. O. (1996). And they is us: Gender issues in science education (Report No. SE-059-543). Washington, DC: U.S. Department of Education. (ERIC Document Reproduction Service No. ED 402 202).

Katsikas, G. (1998). The young aviators mentor program. In D. Findahl (Ed.), Elevating our profession: Flight instructor conference (pp. 159-178). Daytona Beach, FL: Embry-Riddle Aeronautical University.

Kelly, K. R. (1993). The relation of gender and academic achievement to career self-efficacy and interests. Gifted Child Quarterly, 37(2), 59-64.

Kerka, S. (1998). Career development and gender, race, and class (Report No. EDO-CE-95-164). Washington, DC: Office of Educational Research and Improvement. (ERIC Document Reproduction Service No. ED 389 878)

Lankard, B. A. (1995). Family roles in career development (Report No. EDO-CE-95-164). Washington, DC: Office of Educational Research and Improvement. (ERIC Document Reproduction Service No. ED 389 878).

Lent, R. W., Hackett, G., \& Brown, S. D. (1996). A social cognitive framework for studying career choice and transition to work. Journal of Vocational Education Research, 21(4), 3-31.

Lewin, K. (1951). Field theory in social sciences. New York, NY: Harper. 
Mark, R P. (1999). Professional pilot career quide. New York, NY: McGraw-Hill.

Rothwell, R. J., Sullivan, R., McLean, G. N. (eds.) (1995). Practicing organization development: a guide for consultants. Johannesburg: Pfeiffer \& Company.

Stitt-Gohdes, W. L. (1997). Career development: Issues of gender, race, and class (Report No. CE-075-279). Washington, DC: Office of Educational Research and Improvement. (ERIC Document Reproduction Service No. ED 413 533).

Thomberg, H. B. (2000). Women in aviation. In T. Brady (Ed.), The American aviation experience. Carbondale, IL: Southern Illinois University Press.

Turney, M. A. (2000). Attracting women to aviation careers: What recent studies reveal. Collegiate Aviation Review, 18(1) 8692.

Turney, M. A. (1995). Women's learning and leadership styles: Impact on CRM. In McDonald, N., Johnston, N., \& Fuller, R. (Eds.), Proceedings of the $21^{\text {*t }}$ Conference of the European Association for Aviation Psychology (EAAP): Volume 1 (pp. 262-268). Hampshire, England: Avebury Aviation. 